Supplement of Nat. Hazards Earth Syst. Sci., 21, 115-128, 2021

https://doi.org/10.5194/nhess-21-115-2021-supplement

(C) Author(s) 2021. This work is distributed under

the Creative Commons Attribution 4.0 License.

(c) (1)

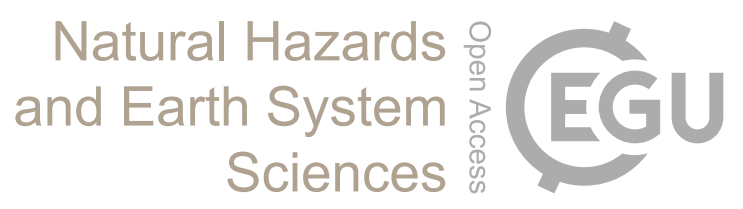

Supplement of

\title{
Beachgoers' ability to identify rip currents at a beach in situ
}

Sebastian J. Pitman et al.

Correspondence to: Sebastian Pitman (sebastian.pitman@canterbury.ac.nz)

The copyright of individual parts of the supplement might differ from the CC BY 4.0 License. 
BEACH SAFETY SURVEY

Please tick the appropriate box \& provide additional information where needed. Most questions are about your beach experiences in general (i.e not about the beach you are visiting today)

\section{A BIT ABOUT YOU...}

Are you:

Male $\quad \square$ Female $\square$ Gender diverse

Are you:

$\square$ Māori $\quad \square$ New Zealand European

$\square$ Samoan $\square$ Cook Islander

$\square$ Tongan $\quad \square$ Niuean

$\square$ Chinese $\quad \square$ Indian

$\square$ Other (please state):

Do you live in New Zealand?

$\square$ Yes $\square$ No
If $n o$, where are you from?

If yes, how many years have you lived in New Zealand?

$\square$ All my life $\square$ More than 10 years

$\square$ 5-9 years $\square$ Less than 5 years

How old are you?

$\begin{array}{ll}\square 0-10 \mathrm{yrs} & \square 40-49 \mathrm{yrs} \\ \square 10-19 \mathrm{yrs} & \square 50-59 \mathrm{yrs} \\ \square 20-29 \mathrm{yrs} & \square 60-69 \mathrm{yrs} \\ \square 30-39 \mathrm{yrs} & \square 70+\mathrm{yrs}\end{array}$

\section{SOME QUESTIONS ABOUT YOUR TIME AT THE BEACH...}

Is this your local beach?

Yes $\square$ No

When you visit the beach, do you (tick all that apply):

Stay in depths of water where you can still stand up

$\square$ Go into water depths greater than your height

$\square$ Swim

$\square$ Surf

$\square$ Other (please state):

How often do you visit beaches in the Summer?

$\square$ Daily $\quad \square 2-3$ times a week

$\square$ Once a week $\square$ Once a month

$\square$ Infrequently
How long have you been visiting the beach this often?

$\square$ Weeks $\quad \square$ Months

$\square$ Years $\square$ Unsure

Can you swim?

$\square$ Yes $\square$ No

If yes, rate your swimming ability:

$\begin{array}{ll}\square \text { Poor } & \square \text { Good } \\ \square \text { Fair } & \square \text { Very good }\end{array}$

How far (in metres) could you swim in a pool without stopping?
Less than 25
101-200
25-50
$\square$ More than 200

口51-100 
How do you feel about swimming that same distance at the beach?
$\square$ Very anxious
$\square$ Confident
$\square$ Anxious
$\square$ Very confident
$\square$ Unsure

When was the last time you swam that distance?

$\square$ This week

$\square$ This month

More than a year ago

$\square$ This year
Can you float effectively on your front and back?
Yes
No
Unsure

Can you swim effectively on your front and back?
$\square$ Yes
$\square$ No
$\square$ Unsure

Can you tread water for more than 2 minutes?

Yes

No

$\square$ Unsure

\section{BEACH HAZARDS}

What do the red/yellow flags mean on a New Zealand beach?

$\square$ Area patrolled by lifeguards

$\square$ Dangerous area of beach

$\square$ For surfers only

$\square$ Unsure

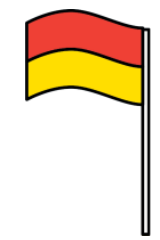

When would you swim outside the patrolled area?

$\begin{array}{ll}\square \text { Never } & \square \text { Anytime } \\ \square \text { If the patrolled } & \square \text { If I want to swim } \\ \text { area is too busy } & \text { long distances } \\ \square \text { Other (please } & \\ \text { specify): } & \end{array}$

How do you choose a safe area to swim at the beach?

What hazards can occur at the beach?
What hazards have you personally experienced at the beach?

Rip currents are a common hazard at the beach for swimmers. What do you think makes a rip current dangerous?

How confident would you feel about coping with a rip current?
$\square$ Very anxious
$\square$ Confident
$\square$ Anxious
$\square$ Very confident
$\square$ Unsure

Have you ever been caught in a rip current?
Yes
No
Unsure 
Do you know what to do if you find yourself accidentally caught in a rip current?
$\square$ Yes
$\square$ No
$\square$ Unsure

If yes, what action(s) would you take?
Could you spot a rip current?

$\square$ Yes $\square$ No $\square$ Unsure

If asked to identify a rip current on a beach, what would you look for?

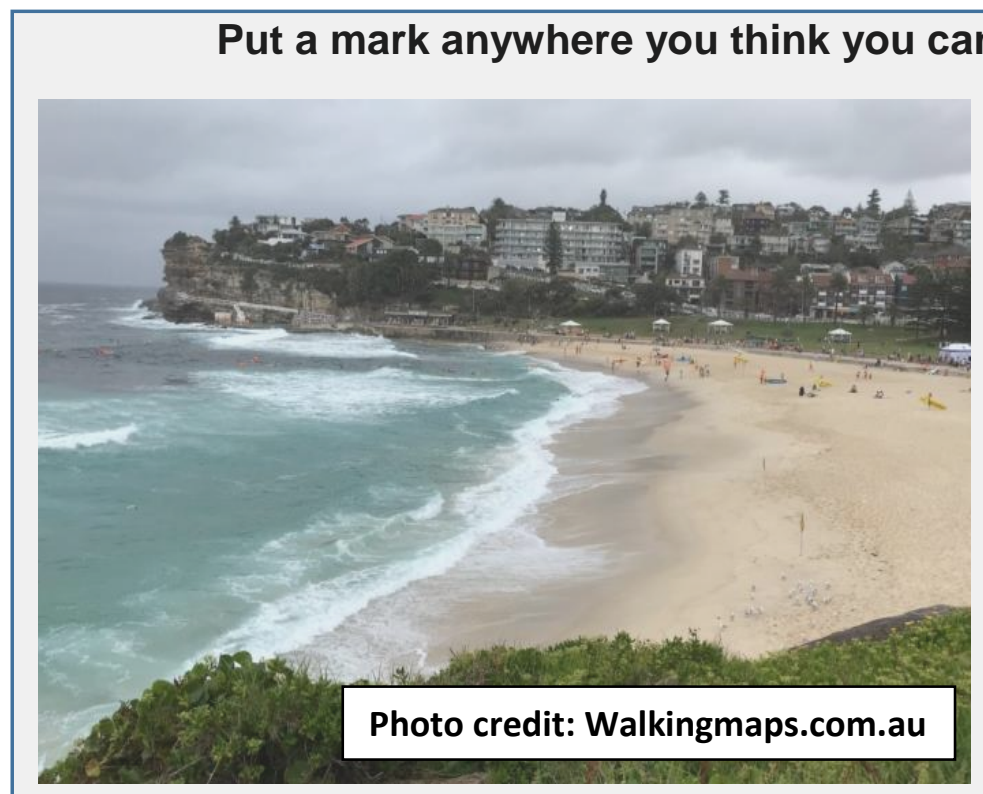

Have you had the opportunity to learn about rip currents before?
$\square$ Yes
$\square$ No
$\square$ Unsure

If yes, how did you learn about rip currents?

Is there any other information you'd like to share about rip currents?

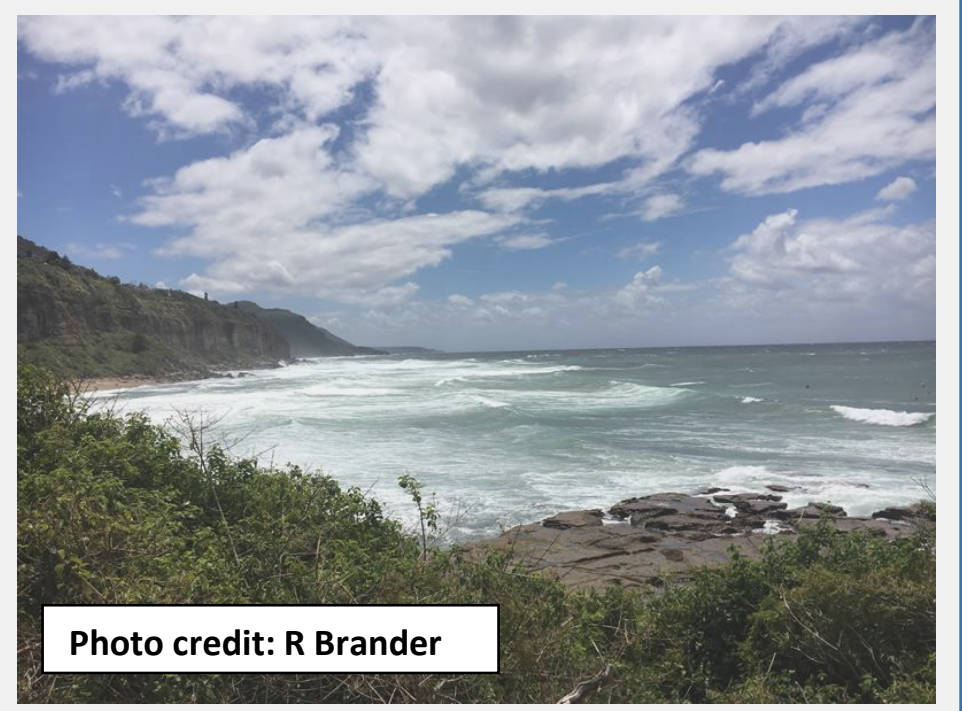

What ways might be best for helping people learn about rip currents? How would you have liked to learn about keeping beach safe and rip currents?

Thank you for taking the time to fill out this survey. Please place your completed survey in the sealed envelope. 